\title{
Universal restrictions to the conversion of heat into work derived from the analysis of the Nernst theorem as a uniform limit
}

\author{
José María Martín-Olallø and Alfredo Rey de Luna \\ Departamento de Física de la Materia Condensada. Universidad de Sevilla. \\ Ap. Correos 1065 E-41080Sevilla. Spain
}

\begin{abstract}
The relationship between the Nernst theorem and the Kelvin-Planck statement of the second law is revisited. We put forward the fact that the exchange of entropy is uniformly vanishing as the temperature goes to zero. The analysis of this assumption shows that is equivalent to fact that the compensation of a Carnot engine scales with the absorbed heat so that the Nernst theorem should be embedded in the statement of the second law.

PACS numbers: 05.70.-a,05.70.Ce

Keywords: First law; Third law; Foundations of Thermodynamics; Second Law; Carnnot engine; Ideal Gases
\end{abstract}

\section{INTRODUCTION}

The classical formulation of the Kelvin-Planck statement of the second law reads: 1 , page 89]

"it is impossible to construct an engine which will work in a complete cycle, and produce no effect except the raising of a weight and the cooling of a heat-reservoir"

Some other, essentially equivalent formulations of the law are possible - Kelvin [2], Clausius [3] and Carathéodory [4] statements - but, for our purpose, we will refer to the formulation posed above. Essentially the statement requires the presence of another reservoir.

The development of the law needs the concept of "working fluid", the substance that undergoes the cyclic process. The properties of the working fluid are usually discarded because the initial and final state of the fluid coincides and "it has done service only as a transmitting agent in order to bring about the changes in the surroundings" [1, page 68]. Nonetheless, the fluid must be able to do "service" in the way required.

We will show in this work that a general property of the matter will be restricting the ability of working fluids to perform cycles thus restricting what the Kelvin-Planck statement allows. We will show that, in fact, such restriction follows from a comprehensive interpretation of the statement posed above.

The general property we are speaking about is nowadays known as the third law of thermodynamics. The necessity and character this law has been a matter of discussion from the early years of 1900's. Some chemical problems lead Nernst [5, [6] to discover his heat theorem which reads $[6$, page 85$]$ :

"in the neighborhood of the absolute zero all processes proceed without alteration of entropy"

*Electronic address: olalla@us.es
The theorem - which classically does not follow from the Kelvin-Planck statement [7, 8] - is supported by a formidable array of experimental data. We choose this elder - though very valuable - version for the reasons that will be disclosed in section 3 but we are seeing no particular reason for this statement to have been forgotten other than it refers to properties of processes rather than to properties of systems as it is nowadays stated 9, 10, 11, 12, 13.

Nernst derived the theorem from two quite general observations. The first one is the so-called principle of unattainability of the zero isotherm which recalls the fact that no process can diminish the temperature of a system to the absolute zero. The second one is the fact that the specific heat of substances goes to zero as the temperature goes to zero.

It should be acknowledge that Planck [1] noticed that these observations should have lead to a "more comprehensive" conclusion: "as the temperature diminishes indefinitely the entropy of a chemical homogeneous body of finite density approaches indefinitely to a definite value, which is independent of the pressure, the state of aggregation and of the special chemical modification." The Planck formulation avoids that $\Delta S \rightarrow 0$ while $S \rightarrow-\infty$ as $T \rightarrow 0$ and thus expresses that the absolute value of the entropy is bounded in the absolute zero.

Yet, our work will be just related to the analysis of $\Delta S$ since it just deals with the analysis of the conversion of heat into work. That problem is insensitive to a translation of the value of the entropy and thus, Planck's formulation lies out of our scope of interest. The same can be said about the vanishing of the specific heats.

Modern approaches and presentations of the third law of thermodynamics usually relates it to the microscopic properties of systems under consideration 14, 15, 16, 17, 18]. Some efforts also try to clarify its macroscopic meaning 19, 20, 21, 22, 23, 24, 25].

The goal of this paper is a revision of the mathematical description of the statement of the Nernst theorem posed above as well as its physical consequences. We will study pure macroscopic observations in the field of low temperature physics. In so doing no hypothesis about the constitution of the systems under study will be con-

Typeset by REVTEX 
sidered.

Also, it is a burden of this manuscript an energetic analysis of the consequences of the statement posed above. To put it shortly, the simplest, most efficient engine contains two processes in which entropy is altered. This kind of processes are restricted at the neighborhood of absolute zero by the Nernst theorem; we will proof that such restriction will lead to a further condition that any engine must satisfy.

\section{LIMITATIONS TO THE DESCRIPTION OF THE NERNST THEOREM}

The classical formulation of the Nernst theorem reads: [9] "the change in entropy associated with any isothermal process between two states of a system in internal equilibrium vanishes in the limit of zero temperature," which is usually translated into the mathematical condition:

$$
\forall x_{1} x_{2} \in \mathcal{D} \quad \lim _{T \rightarrow 0^{+}}\left[S\left(T, x_{1}\right)-S\left(T, x_{2}\right)\right]=0
$$

where $x$ is any mechanical variable such as volume, pressure or magnetic field and $\mathcal{D} \subseteq \mathbb{R}$ is its domain of definition. 28]

Landau and Lifshitz 10 showed the importance of keeping $x_{1}, x_{2}$ fixed in (11). Otherwise, they said, if, for instance, $x_{1}$ goes to infinity, the theorem may no be valid. Quite generally it could be said that that description works fine if the values of $x$ are indeed fixed but it comes into trouble in case one looks for double limits of the form $T \rightarrow 0$ and $x \rightarrow \infty$.

An academic example of this problem is provided by the following naive model

$$
S(T, x)=S_{0}+\chi T x^{g} \Longrightarrow S\left(T, x_{1}\right)-S\left(T, x_{2}\right)=\chi T\left(x_{1}^{g}-x_{2}^{g}\right)
$$

with $x \in \mathbb{R}^{+}$. In this expression $\chi$ is a positive constant that fits the dimensions of the model. Notice that (2) satisfies (11) but the double limit $T \rightarrow 0, x \rightarrow \infty$ depends on the path it is achieved. Figure 1 depicts a $T-S$ plot for a system satisfying (2).

The model does not fulfill the unattainability statement. First, it true that for fixed $x_{1}$ and $x_{2}$ the zero isotherm is unattainable 13]; this proposition is essentially equivalent to (11). Yet, there is no need for so doing if one wants to achieve the neighborhood of the zero isotherm and it is also true that any isentropic path is endless for that model as - let $g>0$ - by increasing indefinitely the mechanical parameter, the temperature is indefinitely decreasing to zero in a single step through $T x^{g}=$ cte. The "unattainability" of the zero isotherm would be a matter of practical limitations - how to get an infinite $x$ - rather than a fundamental restriction posed by a law of nature - strictly speaking the absolute zero is here attained asymptotically.-

Finally, the model does not accomplish for the words given by Nernst - see section 1- either. No matter how

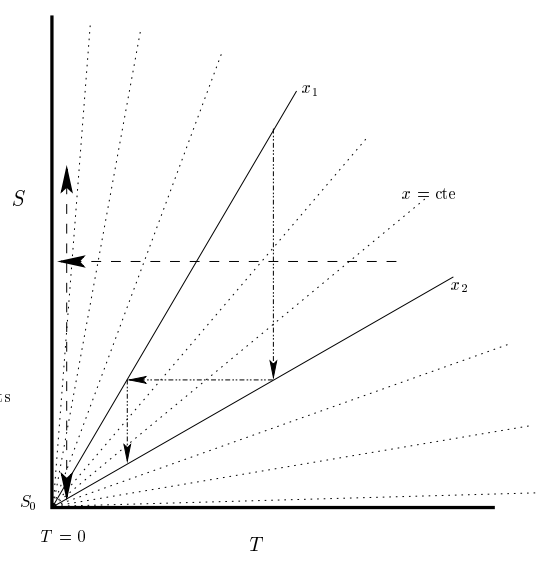

FIG. 1: $T-S$ plot for the model (2). Iso- $x$ lines are depicted. The unattainability statement and (1) are satisfied for fixed $x_{1}$ and $x_{2}$. Yet an isentropic process - horizontal left arrow - diminishes the temperature of the system arbitrarily. Also any alteration of entropy is possible in the neighborhood of $T=0$ - vertical double arrow- provided that $x$ would change appropriately.

close to zero the temperature can be any alteration of entropy is possible provided that the mechanical variable increases sufficiently.

The ideal gas behaves similarly to that model. A classical description of the particles leads to an entropy with no lower bound and which does not accomplish for the Nernst theorem. On the contrary a quantum description of the problem leads to $10,15,18]$ (2) where $x$ is the volume and $g=2 / 3$ for fermions. A deep analysis of the model shows that the quantum or classical description is driven by the condition 10,14 :

$$
\frac{V}{N}\left(\frac{m k T}{2 \pi \hbar^{2}}\right)^{3 / 2} \gg 1
$$

known as "classical limit." Here $N$ is the number of particles, $\hbar$ is Dirac's constant, $m$ is the particle mass and $k$ is the Boltzmann's constant. Thus, the competition between $T \rightarrow 0$ and $V \rightarrow \infty$ is again crucial. It is likely that these contradictions are due to the fact that interactions are unavoidable at the very limit $T \rightarrow 0$ so that microscopically ideal models may not be reflecting the array of data on macroscopic systems [14].

We have shown then that a model satisfying (1) the classical description of the Nernst theorem- does not lead to the unattainability statement. Even worse, it does not fit to the words given by Nernst. Thus, further assumptions are required to a comprehensive and accurate mathematical description of the empirical laws observed at very low temperatures. 


\section{THE NERNST THEOREM AS A UNIFORM LIMIT}

The mathematical description of the statement of the Nernst theorem posed in Sec. 11 is improved by considering the following hypothesis $I$ : the isothermal exchange of entropy is uniformly vanishing as the temperature goes to zero:

$$
\forall \epsilon>0 \quad \exists \delta(\epsilon)>0: T<\delta \Rightarrow\left|S\left(T, x_{1}\right)-S\left(T, x_{2}\right)\right|<\epsilon
$$

The key question 26] of the "uniform convergence" is that the same $\delta(\epsilon)$ fits for any $x_{1}, x_{2}$ belonging to $\mathcal{D}$. It is straightforward that (3) matches the statement posed in section 11 We will argue that it is the best choice to express mathematically that proposition.

The Nernst theorem is classically supposed to be restricting the functional dependence of isothermal exchange of entropy $\Delta S=S\left(T, x_{2}\right)-S\left(T, x_{1}\right)$ on $T$ so that it converges to zero at the absolute zero. The "uniform" condition, here presented, essentially means that no value of $x$ can challenge this convergence. That is, no accidental divergence can possibly occur for a given value of $x$ in the neighborhood of $T=0$. In this way, the Nernst theorem would be also restricting the functional dependence of $\Delta S(T, x)$ on $x$.

a. Rôle of $x$ : If hypothesis I is taken into account, the mechanical variable plays no rôle in the description of the problem. That is the primary consequence of the uniform convergence since given $\epsilon$ then $\delta$ is just a property of the system under consideration regardless the value of $x$. The reader should notice that this is a burden in the formulation of the Nernst theorem as a law of nature which does not depends on the configuration of the system under consideration.

In the classical description of the theorem (1) $\delta$ is a function of $\epsilon, x_{1}, x_{2}$ so the mechanical variable does play a rôle in the description of the problem. Although this rôle is usually discarded it is of the most importance when considering, for instance, double limits.

b. Existence of inaccessible regions in a $T-S$ plot: Equation (3) ensures that $S\left(T, x_{1}\right)-S\left(T, x_{2}\right)$ is bounded in the neighborhood of $T=0$ so that it has a supremum:

$$
\sigma(T)=\sup _{x \in \mathcal{D}}\left\{S\left(T, x_{1}\right)-S\left(T, x_{2}\right)\right\}
$$

The function $\sigma$ exists and is a monotonically increasing function at least in the neighbourhood of $T=0$. The function depends on the thermophysical properties of the system under consideration. What follows describe the relevant properties of the function in that neighbourhood.

Now, consider a system compliant with hypothesis I whose equilibrium state is defined by a given temperature and a given mechanical configuration. The entropy of this state equals $S(T, x)$. Let us suppose that entropy is isothermally increased, the existence of $\sigma$ ensures that the final entropy cannot exceed $S(T, x)+\sigma$. The same argument applies for a process that decrease entropy. Hence, $S(T, x)$ is an upper and lower bounded function of $x$ for a given temperature and exists the following functions:

$$
S_{\text {max }}(T)=\sup _{x \in \mathcal{D}}\{S(T, x)\} ; \quad S_{\text {min }}(T)=\inf _{x \in \mathcal{D}}\{S(T, x)\}
$$

Since the stability condition $(\partial S / \partial T)_{x}>0$ holds in the neighborhood of $T=0$ - except perhaps at $T=0$ the preceding functions are increasing functions of $T$ so that states of the type $\left\{T, S>S_{\max }(T)\right\}$ and $\{T, S<$ $\left.S_{\text {min }}(T)\right\}$ cannot exist. Hence, equilibrium states do not fill the plane $T-S$ and two boundaries arises from the fulfillment of the Nernst theorem as an uniform condition.

In more detail it could be said that one of the goals of the third law is to ensure that the entropy $S$ has a single value in the neighborhood of zero isotherm $[9]$. In the classical formulation of the theorem, points of the type $\left\{T=0, S \neq S_{0}\right\}$ are excluded [9, Figure 23.5] in a $T-S$ plot (these points are sketched by the symbol $\times$ in figure 2). From a physical point of view "when a certain point is excluded, we must demand that the same must be true about a small region surrounding the point" [4] 27, page 236].29] On the contrary, if a neighborhood of $\{T=$ $\left.0, S \neq S_{0}\right\}$ could be reached, the exclusion of those isolated-points would be fictitious.

Thus, the plot $T-S$ (see figure 2) consists in the region I of allowed values of $\{T, S\}$, and the forbidden region II. The existence of region II is a goal of hypothesis I. The boundaries - which may or may not be physically accessible- does not coincide with the axis $T=0$. In Figure 2 and in the preceding discussion we have make use of the Planck hypothesis for the purpose of clarity. The same argument would apply if $S_{0}$ comes down to $-\infty$ and, simultaneously, $\Delta S$ is vanishing.

The following issue is known, however hypothesis I enriches and clarifies its meaning.

c. Processes that come to an end (unattainability statement): Let us consider the isentropic process $S=$ $\Sigma_{0}$ starting at some temperature so that $S_{\text {min }}<\Sigma_{0}<$ $S_{\max }$. The process will go on until the temperature $T_{1}$ defined by $S_{\max }\left(T_{1}\right)=\Sigma_{0}$ is attained. That temperature is non zero.

Here we may decrease the entropy of the system isothermally until the condition $\Sigma_{1}=\Sigma_{0}-\sigma\left(T_{1}\right)=$ $S_{m i n}\left(T_{1}\right)$ is achieved. At that point, an isentropic process will cool the system down to the temperature $T_{2}$ defined by $S_{\max }\left(T_{2}\right)=\Sigma_{1}$.

The endless staircase process that goes to the absolute zero is then defined.

d. Vanishing of the thermal expansions coefficients The thermal coefficients are related to the derivative $(\partial S / \partial x)_{T}$ through Maxwell's relations [9]. From (3) it is derived the vanishing of such derivative since:

$$
\lim _{T \rightarrow 0}\left(\frac{\partial S}{\partial x}\right)_{T}=\lim _{T \rightarrow 0} \lim _{x^{\prime} \rightarrow x} \frac{S\left(T, x^{\prime}\right)-S(T, x)}{x^{\prime}-x} \quad \forall x \in \mathcal{D}
$$




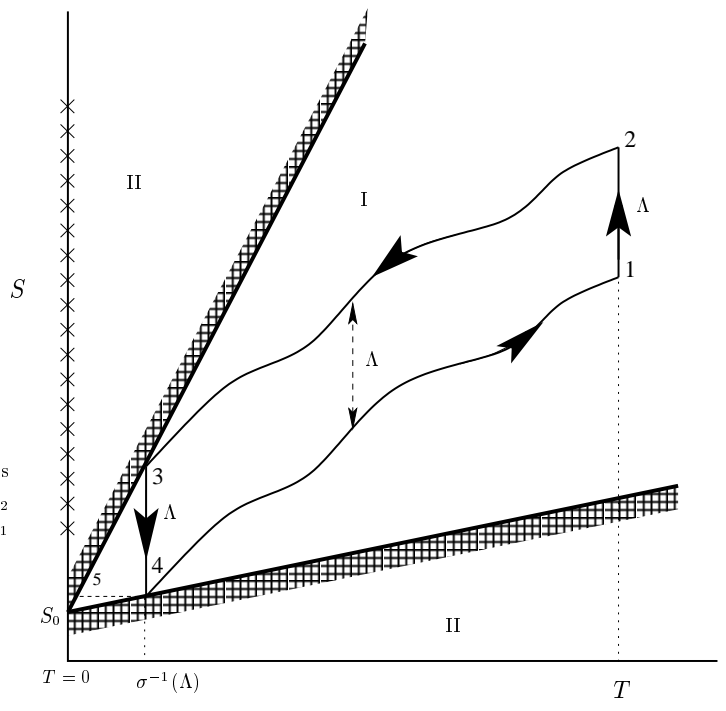

FIG. 2: The $T-S$ plot and the Nernst theorem. The symbol $\times$ represents the points classically excluded by the theorem 9 , Figure 23.5]. A more comprehensive analysis of the theorem reveals that there exist a region I whose points represents equilibrium states, and a region II which does not do so. The cycle 1-2-3-4-1 is an engine consisting in two isotherms 1-2 and 3-4, and two processes, 2-3 and 4-1, which differ just in a shift of entropy $S^{\prime}=S+\Lambda$. Area 1-2-3-4-1 is equal to $\Lambda\left[T-\sigma^{-1}(\Lambda)\right]$ as in a Carnot engine. The essential of this picture is valid even if $S_{0} \rightarrow-\infty$ while $\Delta S \rightarrow 0$

If this double limit exists, it can be computed in whichever order. By taking first $T \rightarrow 0$ and invoking (3) one has, of necessity [9]:

$$
\lim _{T \rightarrow 0}\left(\frac{\partial S}{\partial x}\right)_{T}=0 \quad \forall x \in \mathcal{D}
$$

Unlike properties a and $\mathrm{b}$-being mathematical propositions, - it should be pointed out that properties c and d are trends $[6,9]$ amply confirmed by experiment providing a support for the hypothesis. Yet, the most important consequence of the hypothesis relates it to the problem of the conversion of heat into work and will be considered in detail in the following section.

\section{THE NERNST THEOREM AND THE CONTINUOUS PRODUCTION OF WORK}

In the preceding section we have shown that the Nernst theorem forces the existence of forbidden regions in a $T-S$ plot. We now derive consequences taking in mind that the uniformity condition introduced in the preceding section makes $x$ play no rôle in the problem.

Let us now consider the following question: we wish to build up an engine which produces mechanical work $W$ by using a given working fluid that draws a given amount of heat $Q$ from a reservoir of a given temperature
$T$, which is the minimal amount of heat $Q_{m i n}^{\prime}$ that is to be taken up to the cold reservoir? 30]

The classical reading of the Kelvin-Planck statement would just say that the heat taken up at the cold reservoir - hereafter called "compensation" - must be nonzero $Q^{\prime} \neq 0$. It then seems that so long as this statement is concerned, a negligible $Q^{\prime}$ would suffice. Thus, $Q_{m i n}^{\prime}=0^{+}$-ie arbitrarily close to zero but non-zero- . The answer is independent from $Q, T$ and the working fluid and comes from the fact we feel free to place a tworeservoir engine in a $T-S$ plot since no other restriction happens to be.

A machine having $Q_{\text {min }}^{\prime}=0^{+}$would result in an efficiency $\eta=W / Q$ as close to unity as desired. This most efficient engine has never been built up; we will now put forward the fact that this is due to fundamental properties of matter despite of practical limitations to achieve such engine.

As a general rule, $\sigma$ is nonzero for nonzero temperatures and from (3) and (4) one gets:

$$
\forall \epsilon>0 \quad \exists \delta(\epsilon)>0: \quad T<\delta \Longrightarrow \sigma(T)<\epsilon
$$

That is, $\lim _{T \rightarrow 0^{+}} \sigma(T)=0$.

In (7) there is no need to call for absolute value delimiters since both $T$ and $\sigma$ are positive magnitudes. From (17) and the preceding argument the existence of the inverse function $\sigma^{-1}(\Lambda)$ is straightforward. In fact, the inverse function is nothing else but a suitable representation for the parameter $\delta(\epsilon)$. The inverse function gives the temperature at which the width in entropy of the accessible states equals $\Lambda$. That temperature also depends on the thermophysical properties of the system under consideration.

Now, let us consider again the question posed at the beginning of this section but now consider that the KelvinPlanck statement and the Nernst theorem, as stated in section [1] apply. Hence, the restrictions posed in section 3 shown in figure 2 are valid. The working fluid is undergoing a cycle that is extracting an amount of entropy $\Lambda=Q / T$ from the hot reservoir. For so doing, it is necessary that $\Lambda<\sigma(T)$.

Now, the entropy should be being deposited into the cold reservoir which would receive an amount of heat $Q^{\prime}$. To achieve the maximum efficiency, the temperature of the cold reservoir must be the coldest temperature able to exchange with the working fluid that amount of entropy. Following the preceding paragraphs, that minimal temperature is given by $\sigma^{-1}(\Lambda)$ which is a property of the fluid under consideration. Thus,

$$
\begin{array}{r}
\forall Q \neq 0, T \neq 0: \frac{Q}{T}=\Lambda<\sigma(T) \\
\Longrightarrow \exists \sigma^{-1}(\Lambda): Q^{\prime} \geq \Lambda \times \sigma^{-1}(\Lambda)=Q_{m i n}^{\prime}
\end{array}
$$

This most efficient engine is depicted in figure 2 by the cycle $1-2-3-4-1$ which consists of two isotherm and two processes that differ in a shift of entropy; exchanges of energy and entropy in $2-3$ cancel with those of $4-1$ 


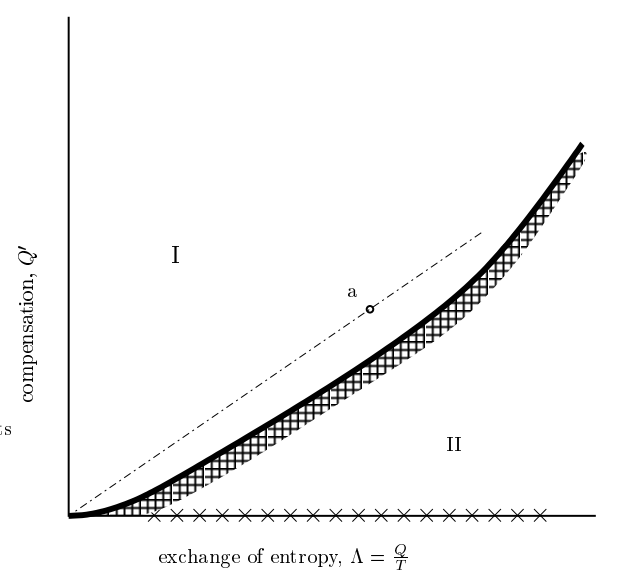

FIG. 3: Plot of $\Lambda-Q^{\prime}$ for a given working fluid. A point of region I, say $a$, represents a set of engines each having the same $Q^{\prime}$ and $\Lambda$ and the same temperature of the cold reservoir: the slope of the straight line. The thick line - which depends on the working fluid - represents (8) and comes to $\{0,0\}$ with zero slope. For the working fluid under consideration, it is impossible to built up an engine that enters in region II. The symbol $\times$ represents the restriction posed by the classical reading of the Kelvin-Planck.

so the reservoirs needed for these two processes play no rôle in the problem. 31] The performance of work equals to $W_{\max }=\Lambda \times\left[T-\sigma^{-1}(\Lambda)\right]$.

It is very noticeable that the value of $Q_{\min }^{\prime}$ is now a function of the parameters of the problem: $Q, T$ and the working fluid which enters through $\sigma^{-1}$. Moreover, the minimal compensation is a function of the exchange of entropy $\Lambda$.

Though the particular value of $Q_{\min }^{\prime}$ depends on the thermophysical properties of the working fluid it is a quite noteworthy fact that, as a general rule, $Q_{\min }^{\prime}$ is never arbitrarily close to zero for a given $\Lambda$ since, according to the Nernst theorem, $\sigma^{-1}$ is not arbitrarily close to zero either (see figure 2).

The universal resemblance of (8) allow to outline the plot $\Lambda-Q^{\prime}$ (see figure 3). Notice that in the context of the classical reading of the Kelvin-Planck statement that plot would have no restriction other than the exclusion of the points of the type $\left\{\Lambda \neq 0, Q^{\prime}=0\right\}$, those points are shown in that figure by the symbol $\times$. Now, if we take into account the Nernst theorem it is clear that points of the type $\left\{\Lambda, Q^{\prime}<Q_{m i n}^{\prime}(\Lambda)\right\}$ should be excluded as well. That points define a region whose boundary is given by (8); the analogy between the regions I and II, and the boundary of figure 2 and those of figure 3 is immediate. From the Nernst theorem it is easily probed that $Q_{m i n}^{\prime}$ goes to zero with zero slope as $\Lambda$ goes to zero. Summarizing the meaning of figure 3 it should be stressed that the Nernst theorem is excluding a region around those points actually excluded by the classical reading of the Kelvin-Planck statement. That is in agreement with Carathéodory's argument posed in section 3 .
The limit $\Lambda \rightarrow 0^{+}$is the unique possibility to get $Q_{\text {min }}^{\prime} \rightarrow 0^{+}$. In that case, taking $T$ as a bounded, constant parameter, it is clear that $Q$ will be vanishing as well and, as an ultimate consequence $W$ will be also vanishing. Hence:

$$
Q^{\prime} \rightarrow 0^{+} \Longrightarrow W \rightarrow 0^{+}
$$

This proposition contains the essence of the Nernst theorem. Its dramatic meaning is best viewed noticing that $Q^{\prime} \rightarrow 0^{+}$and $\eta \rightarrow 1^{-}$are equivalent. It then means that as the most efficient engine is achieved, the delivery of work is decreasing to zero.

It should be pointed out once again that in the preceding discussion $x$ does not play any rôle and it is in this sense that the restrictions figure 3 and (9) are universal. That feature comes from the property of uniformity. On the contrary, if the Nernst theorem is just considered as a limit — without the requirement of uniformity,- then (9) and figure 3 would be just valid for transitions between two given values of $x$ - see [9, Figure 23.9] 23].Therefore, (11) does not lead to any proper restriction, as the boundary of figure 3 will come arbitrarily close to the restriction posed by the classical reading of the KelvinPlanck statement provided that we consider the appropriate values for $x_{1}$ and $x_{2}$. Hence, the improvement of an engine would be a matter of practical limitations if (1) were valid. 32]

\section{THE NERNST THEOREM AND THE STATEMENT OF THE SECOND LAW}

Section 4 clearly shows that the Nernst theorem is restricting the conversion of heat into work in a way which is independent from the mechanical configuration of the system. It should be desirable to link it to the KelvinPlanck statement of the second law.

One of the most important results of section 4 is the leading rôle played by $Q^{\prime}$, the compensation, in the problem of the conversion of heat into work. That importance comes from the fact that its minimum value is universally expressed by (8).

From an historical point of view, the rôle of the cold reservoir was the key of the second law. The first known statement of the law, due to Kelvin [2], stated that it is impossible to built up an engine that both produces work and cools the coldest of the available reservoirs, no matter what happens to hotter reservoirs (see figure 4).

Planck simplified the statement by noticing that it is impossible to built up an engine that performs work by cooling just one reservoir [1]. In that sense, a cold reservoir is to be heated - compensation - in some amount (see figure 4). Yet he put forward no word about the "size" of the compensation so that one hopes it might be negligible: that is the "classical" reading of the statement that has prevailed from the beginning of the statement.

Furthermore, if the Nernst theorem is taken into account through hypothesis I, we get the ultimate restric- 


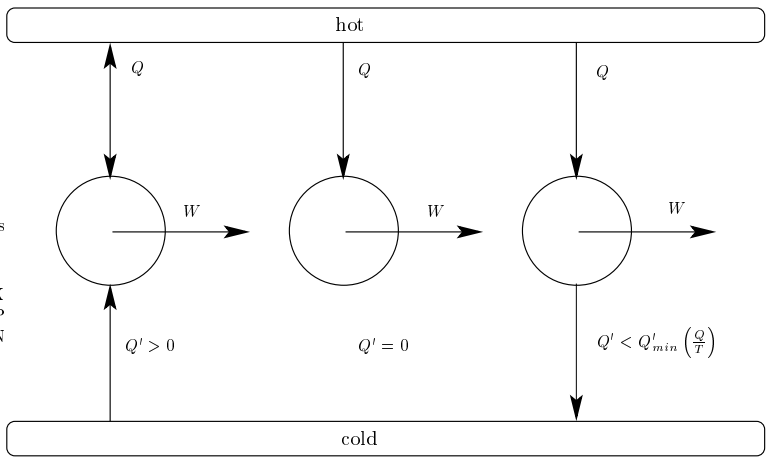

FIG. 4: The staircase of the statements of the second law. The reader should notice the restrictions on the compensation that arises from the violations of the statements. From left to right a violation of the Kelvin statement, of the classical reading of the Kelvin-Planck statement, and of a "comprehensive" reading of the Kelvin-Planck statement. In this last case, $Q_{\text {min }}^{\prime}$ is given by 8 .

tion: a minimal compensation is given by the properties of the working fluid and the exchange of entropy (see (8) and figure 4): wish you to transform a finite amount of heat into work, you must certainly pay a tax - a compensation -, namely the tax is not becoming finiteless at your willing. The emphasized proposition is an informal statement for (9).

The reader should notice that, in fact, (9) is something else than the bare statement of the Nernst theorem since it also recalls the Kelvin-Planck statement. It is the dome that crowns the leitmotif of the principles of thermodynamics by putting forward the ultimate restriction on $Q^{\prime}$. In fact, if the relation were clothed in a negative way the reader would have found a statement very much like any of the second law: it precludes delivering a finite work without a finite compensation.

\section{FROM THE KELVIN-PLANCK STATEMENT TO THE NERNST THEOREM}

The preceding sections analyzed the Nernst theorem through the hypothesis I putting forward its close relation to the problem of the conversion of heat into work. Here we want to do the reverse trip: starting at the KelvinPlanck statement, upon which assumptions is hypothesis I derived?

In our opinion the classical reading of the KelvinPlanck statement could be said to be "crude" in the sense that the cause - heat absorbed from the hot reservoir - and the unavoidable effect - the minimal compensation - has been being taking as uncoupled since the early stage of thermodynamics. A more comprehensive reading of the statement of the second law would have lead to some coupling between the $W_{\max }$ or $Q_{\min }^{\prime}$ and $Q$ since a finiteless absorbed heat is necessary to get a finiteless compensation - see (8) and figure 2-We put now forward the fact that this hypothesis - labeled hypothesis II - suffice for the Nernst theorem:

the compensation of a Carnot engine approaches indefinitely zero only if the heat $a b$ sorbed from the reservoir is vanishing

The significance of the hypothesis would be revealed by the conclusions that it draws, however the reader should not conclude that hypothesis II is additional to the Kelvin-Planck statement since it is embedded in its words. The point is the meaning of the word "effect" that appears in the statement. One can get explicitly hypothesis II by changing "effect" by "finite effect" in the statement so that any "finite" absorbed heat necessarily leads to a "finite" compensation. But, in fact, any effect is actually finite so that the modification would be a pleonasm.

The fact that the hypothesis leads to the Nernst theorem is surprisingly straightforward. Notice that the compensation of an engine equals $Q^{\prime}=T^{\prime} \times \Lambda$ where $T^{\prime}$ is the temperature of the cold reservoir and $\Lambda$ the exchange of entropy. That magnitude becomes zero (1) if $T^{\prime}$ goes to zero regardless $\Lambda$ or (2) if $\Lambda$ goes to zero regardless $T^{\prime}$. The hypothesis excludes option (1) that is, it excludes any alteration of entropy in the neighbourhood of the absolute zero. Hence, the Nernst theorem as stated in section 1 and as analyzed in section 3 comes of necessity.

It is then concluded that hypothesis I and II are equivalent propositions so that the Nernst theorem ultimately follows from a comprehensive reading of the KelvinPlanck statement through hypothesis II. 33 This proposition is valid as far as systems suitable to be working fluids of engines are being considered.

\section{DISCUSSION AND CONCLUSION}

In 1909 Carathéodory [4], following a suggestion by Born, successfully translated the classical statements of the second law - which deal with the problem of production of work - into a statement which refers to physical properties of an isolated system. This work introduces the reverse trip for the Nernst theorem. The theorem has been supposed to deal with the properties of systems in the neighborhood of $T \rightarrow 0$; the study here presented (see section 4 specially (8) and (9) ) relates the theorem back to the problem of production of work. The theorem will be expressing an universal property of the continuous production of work.

The reader may ask which assumptions makes the Nernst theorem independent from the Kelvin-Planck and which does not do so. The goal of the second law of thermodynamics is to restrict the continuous production of work putting forward the existence of a fundamental asymmetry: work is dissipated into heat but the reverse is not true. The goal enters by a statement which expresses, in words, a restriction. We have shown in this paper that the degree of restriction matters and gets influence 
in the properties of systems. The classical reading of the Kelvin-Planck statement assumes just that the compensation is nonzero. Upon this assumption the general properties of systems in the neighborhood of $T=0$ needs to be summarized as an independent law. Yet, a comprehensive reading of the statement through the cautious hypothesis II presented in section 6leads to some of these general properties: the unattainability statement and the vanishing of the expansion coefficients. We should again recall that the formulation here presented is insensitive to whether or not specific heats come to zero as the temperature comes to zero.

The new reading of the statement overcomes the embarrassing fact that $W$ must differ from $Q$ - to what extend? - by stating that they must do so in a measurable quantity which also depends on the working fluid which does play a rôle in the problem. The speech of Carathéodory quoted in section [3] again makes the sense in this discussion: if the condition $W=Q$ is excluded, $W=Q^{-}$should have been excluded as well. 34

Any exception to the hypothesis would result in a failure of the consequences $i i i$ and $i v$ quoted in section 3 that is: (a) an experiment that would allow to increase $1 / T$ indefinitely, (b) an experiment that would allow to decrease entropy indefinitely, or (c) a substance that would have non zero thermal expansion coefficients. 35.

It is out of the scope of this paper to describe the microscopic relevance of the hypothesis, that is to determine which kind of Hamiltonians - interactions - would lead to uniformly vanishing $\Delta S$ as well as their symmetry properties. Well-known models - specially ideal gasesdo not satisfy the hypothesis here presented. However the reader should not consider them as an "exception" to the hypothesis since the hypothesis are grounded on experimental macroscopic basis and not on the analysis of microscopic models.

The relation between interactionless models and the Nernst theorem has been recently suggested [14, 17] and it seems that the rôle of interactions can not be neglected in real systems at sufficiently low temperatures. The suggestion comes from the analysis of the independent spin system. That model does not satisfies the Nernst theorem since the ground state is degenerate. Yet, independent spin systems does not happen in nature since real solids always exhibits magnetic correlation and ordering at sufficiently low temperatures. The resulting ordering - usually a macroscopic new phase, either ferromagnetic or antiferromagnetic - would satisfy the Nernst theorem.

Quite the same analysis can be made on free particle systems. The reader should notice that the classical ideal gas allow to envision a process of the type (a) and (b), moreover it satisfies (c) in contradiction with the Nernst theorem. On its own, quantum ideal gases 10] gets vanishing thermal expansion coefficients and precludes experiment of the type (b) since entropy is necessarily a low bounded function. Yet, the quantum model still allows to envision type (a) experiments which do not happen to be in nature and which do preclude the meaning of the Nernst theorem. Of course in real systems "ordering" does always occur and the settlement of condensed phases seems unavoidable.

It is then likely that interactionless models - either kinetic, magnetic or whichever- do not accurately describe the properties of real systems at sufficiently low temperatures since interactions can not be neglected.

\section{Acknowledgments}

The authors wish to thank to Mr. José Antonio Pérez Gómez for long discussions and, specially, for enlightening them with the uniform convergence. The authors also thanks to Ms. Pilar Núñez for her kindly search of old bibliographic data.

This work was supported by Spanish Ministerio de Ciencia y Tecnología project BFM2002-02237.
[1] M. Planck, Treatise on Thermodynamics (Longmans, 1927).

[2] W. Thomson, Trans. Roy. Soc. Edinb. 20, 261 (1853).

[3] R. Clausius, Ann. Phys. Lpz. xciii, 481 (1854).

[4] C. Carathéodory, Mathematischen Annalen 67, 355 (1909).

[5] W. Nernst, Nach. kgl. Ges. Wiss. Göttingen 1 (1906).

[6] W. Nernst, The New Heat Theorem: Its Foundations in Theory and Experimental (Dover, 1924), translation from 2nd German ed.

[7] A. Einstein, in La structure de la matière (GauthiersVillars, 1921), Rapports et discussion du Conseil de Solvay (1913), pp. 294-295.

[8] P. Epstein, A Textbook of Thermodynamics (John Wiley and Sons, 1937).

[9] J. Kestin, A course in Thermodynamics, vol. II (Blaisdell Pub. Co., 1968).
[10] L. Landau and E. Lifshitz, Statistical Physics (Pergamon Press, 1968).

[11] P. Landsberg, Thermodynamics and Statistical Mechanics (Oxford Univ. Press, 1978).

[12] R. Baierlein, Thermal Physics (Cambridge University Press, 1999), ISBN 0-521-65838-1.

[13] M. Zemansky, Heat and Thermodynamics (McGraw-Hill, 1968).

[14] R. Balian, From microphysics to macrophysics (Springer Verlag, Berlin Heidelberg, 1991).

[15] K. Huang, Statistical Mechanics (John Willey and Sons, 1987), ISBN 0-471-85913-3.

[16] S. Mafé and J. de la Rubia, American Journal of Physics 66, 277 (1998).

[17] C. Rose-Innes, American Journal of Physics 67, 27 (1999).

[18] J. Wu and A. Widom, Physical Review E 57, 5178 
(1998), esta en pdf.

[19] G. Falk, Physical Review 115, 249 (1959).

[20] Z. Yan and J. Chen, Journal of Physics A: Math. Gen. 21, 707 (1988).

[21] P. Landsberg, Journal of Physics A: Math. Gen. 22, 139 (1989).

[22] I. Oppenheim, Journal of Physics A: Math. Gen. 22, 143 (1989).

[23] R. Liboff, Physics Essays 7, 95 (1994).

[24] P. Landsberg, American Journal of Physics 65, 269 (1997).

[25] F. Belgiorno, Journal of Physics A: Math. Gen. (2003), physics/0210037.

[26] D. Jones, The theory of generalised functions (Cambridge University Press, 1982), ISBN 0521237238.

[27] J. Kestin, ed., The Second Law of Thermodynamics, vol. 5 of Benchmark Papers on Energy (Dowden, Hutchinson \& Ross, Inc., 1976).

[28] Nernst himself clothed (1) through the statement posed in section 1 6, page 85]

[29] Carathédory is here speaking about the adiabatic inaccessibility and he is preparing his celebrated Axiom II. It is noteworthy that the Axiom literally states that "(...) there exist states that cannot be approached arbitrarily close by adiabatic process" instead of bare phrase "states that are inaccessible by adiabatic process." The concept "arbitrarily close" or "neighborhood" will play a leading rôle in the following discussion.

[30] This question inspects the behaviour of $W$ - or $Q^{\prime}$ - once the hot reservoir and the absorbed heat are fixed. It is also customary to inspect the behaviour of $W$ once the hot and cold reservoirs are fixed. This problem is related to the concept of irreversibility [10] and lies out of the scope of the following discussion.

[31] It would be possible to decrease $Q^{\prime}$ by considering the cycle $1-2-3-5-4-1$-see figure 2- because entropy will be being deposited to colder reservoirs, but the condition of two reservoirs is broken. However, in that case, the compensation is equally expressed by $\sigma^{\prime \prime} \Lambda$ where $\sigma^{\prime \prime}$ is an unknown temperature ranging between $T_{5}$ and $T_{4}=\sigma^{-1}(Q / T)$. The essential of the following discussion also applies to this compensation.

[32] If the working fluid behaves like (2), the engine could always be improved by getting arbitrarily large values of $x$.

[33] Thus the second law ensures that the entropy goes to a value which does not depend on $x$ at the absolute zero. Its precise value, or whether this value is finite or infinite -Planck's formulation - is alien to this description since the second law just concerns variations of entropy.

[34] We are presenting an analogy between the words by Carathéodory and the results of this work. It is not our willing to state that the former derives from the latter or conversely. It is a sort of coincidence that both problems speak about the same law of nature.

[35] The reader should notice that the unattainability of the zero isotherm does not guarantee the Nernst theorem. The model $S(T, x)=\chi \log T \times(x+a) /(x+b)$ with $\chi, a \neq b>0, x \in \mathbb{R}^{+}$provides a mathematical example of system which precludes experiments (a) and (b) but fails to obey the Nernst theorem. 


\title{
Restricciones universales a la conversión del calor en trabajo que provienen del análisis del teorema de Nernst como un límite uniforme
}

\author{
José María Martín Olalla* y Alfredo Rey de Luna \\ Departamento de Física de la Materia Condensada. Universidad de Sevilla. \\ Ap. Correos 1065 E-41080Sevilla. Spain
}

\begin{abstract}
Se analiza la relación entre el teorema de Nernst y el enunciado de Kelvin-Planck del segundo principio de la termodinámica. Señalamos el hecho de que el cambio de entropía tiende uniformemente a cero cuando la temperatura tiende a cero. El análisis de esta hipótesis muestra que es equivalente al hecho de que la compensación de una máquina de Carnot escala con el calor absorbido del foco caliente de forma que el teorema de Nernst puede derivarse del enunciado del segundo principio.
\end{abstract}

PACS numbers: 05.70.-a,05.70.Ce

Keywords: Primer principio, Segundo principio, Tercer principio, Fundamentos de termodinámica, Gases ideales, Máquinas de Carnot, Inaccesibilidad del cero absoluto, Calores específicos

\section{INTRODUCCIÓN}

La formulación clásica del enunciado de Kelvin-Planck establece que: 1, pág. 89]

es imposible construir una máquina que trabaje de forma cíclica y no produzca otros efectos más que la elevación de un cuerpo y el enfriamiento de una fuente

Existen otras formulaciones que son esencialmente equivalentes a ésta — enunciados de Kelvin 2], Clausius 3. y Carathéodory [4] - pero, para nuestro análisis, nos referiremos a la formulación señalada arriba. Esencialmente el enunciado requiere "otra" fuente para realizar el proceso señalado.

El desarrollo del principio necesita del concepto de "fluido de trabajo", la sustancia que realiza el ciclo. Sus propiedades se eliminan normalmente del análisis puesto que el estado inicial y final del fluido coinciden y "sólo ha servido como agente para llevar a cabo cambios en sus alrededores" 1, pág. 68]. Sin embargo, el fluido debe ser capaz de realizar el proceso que se desea.

Mostraremos en este trabajo que una propiedad general de la materia restringe la habilidad de los fluidos de trabajo para realizar ciclos termodinámicos y, por tanto, restringe lo que el enunciado de Kelvin-Planck permite. Mostraremos que esta restricción proviene, realmente, de una interpretación adecuada del enunciado reseñado arriba.

La propiedad general de la que estamos hablando se conoce hoy en día como la tercera ley de la termodinámica. La necesidad y carácter de tal ley ha sido objeto de discusión desde el principio del siglo pasado. El estudio de algunos problemas químicos llevó a Nernst [5, 6] a descubrir su teorema del calor el cual establece que 6, pág. 85]:

*Correo electrónico: olalla@us.es en las proximidades del cero absoluto todo proceso transcurre sin alteración de entropía

El teorema - que clásicamente no proviene del enunciado de Kelvin-Planck 7, 8] — está avalado por una ingente cantidad de datos experimentales. Hemos elegido esta antigua - aunque meritoria - versión del teorema por las razones que se verán en la sección [3 pero no vemos otra razón para que se haya olvidado este enunciado más que el hecho de que se refiere a propiedades de "procesos" en vez de propiedades de "sistemas" tal y como hoy en día se recoge en la literatura científica 9, 10, 11, 12, 13.

Nernst derivó su teorema de dos observaciones de carácter general. La primera es el llamado principio de inaccesibilidad del cero absoluto que señala que ningún proceso puede disminuir la temperatura de un sistema hasta el cero absoluto. El segundo es el hecho de que los calores específicos tienden a cero conforme la temperatura tiende a cero.

Debe reconocerse que Planck[1] señaló que estas observaciones debieron haber llevado a una conclusión más restrictiva: "cuando la temperatura de disminuye indefinidamente, la entropía de un cuerpo químicamente homogéneo de densidad finita se aproxima indefinidamente a un valor que es independiente de la presión, estado de agregación y de las modificaciones químicas." La formulación de Planck evita que $\Delta S \rightarrow 0$ mientras $S \rightarrow-\infty$ cuanto $T \rightarrow 0$ y expresa que el valor absoluto de la entropía está acotado en el cero absoluto.

Sin embargo, nuestro trabajo se relaciona únicamente con el análisis de $\Delta S$ puesto que sólo trata con el problema de la conversión del calor en trabajo. Este problema es invariante frente a una traslación del valor de la entropía y, por eso, la formulación de Planck está fuera de nuestro ámbito de trabajo. Lo mismo puede decirse de la anulación de los calores específicos.

La presentaciones actuales del tercer principio normalmente lo relacionan con las propiedades microscópicas de los sistemas objeto de estudio 14, 15, 16, 17, 18]. También se han hecho algunos esfuerzos para clarificar su significado macroscópico [19, 20, 21, 22, 23, 24, 25]. 
El objetivo de este trabajo es una revisión de la descripción matemática del enunciado del teorema de Nernst señalado anteriormente así como de sus consecuencias físicas. Analizaremos observaciones macroscópicas en el rango de la física de muy bajas temperaturas. Al hacer esto no estableceremos hipótesis alguna sobre la constitución de los sistemas objeto de estudio.

Es también un objetivo de este trabajo un análisis energético de las consecuencias del teorema de Nernst. Brevemente, el motor más simple y eficiente contiene dos procesos en los que se intercambia entropía. Este tipo de procesos está restringido por el teorema de Nernst en las cercanías del cero absoluto. Probaremos que tal restricción lleva a una condición adicional que toda máquina debe satisfacer.

\section{LIMITACIONES A LA DESCRIPCIÓN DEL TEOREMA DE NERNST}

La formulación clásica del teorema de Nernst establece que: 9] "el cambio de entropía asociado con cualquier proceso isotermo entre dos estados de un sistema en equilibrio interno tiende a cero cuando la temperatura tiende a cero," que se expresa matemáticamente como::

$$
\forall x_{1} x_{2} \in \mathcal{D} \quad \lim _{T \rightarrow 0^{+}}\left[S\left(T, x_{1}\right)-S\left(T, x_{2}\right)\right]=0
$$

donde $x$ representa a cualquier variable mecánica como el volumen, presión, campo magnético y $\mathcal{D} \subseteq \mathbb{R}$ es su dominio de definición. 29]

Landau y Lifshitz 10] mostraron la importancia de mantener $x_{1}, x_{2}$ fijas en (11). De otra forma, dicen, si, por ejemplo, $x_{1}$ tiende a infinito el teorema puede no ser válido. En general puede decirse que la descripción del teorema funciona bien mientras que los valores de $x$ están fijos pero entra en contradicciones si se analizan límites dobles como $T \rightarrow 0$ y $x \rightarrow \infty$.

Un ejemplo académico de este problema lo proporciona el siguiente modelo:

$S(T, x)=S_{0}+\chi T x^{g} \Longrightarrow S\left(T, x_{1}\right)-S\left(T, x_{2}\right)=\chi T\left(x_{1}^{g}-x_{2}^{g}\right)$

con $x \in \mathbb{R}^{+}$. En esta expresión $\chi$ es una constante positiva que provee las dimensiones apropiadas. Obsérvese que (2) satisface (1) pero el límite doble $T \rightarrow 0, x \rightarrow \infty$ depende del camino por el que se recorre. La figura 1 muestra un diagrama $T-S$ para este modelo.

El modelo no satisface el principio de inaccesibilidad del cero absoluto. Primero, es cierto que para unos valores fijos de $x_{1}$ y $x_{2}$ el cero absoluto sí es inaccesible [13]; esta proposición es equivalente a (1). Sin embargo no hay necesidad de hacer esto si lo que se desea es acceder al cero absoluto; y no es menos cierto que un cualquier proceso isentrópico no tiene fin puesto que - si $g>0-$ al aumentar indefinidamente el parámetro mecánico se disminuye indefinidamente la temperatura del sistema en

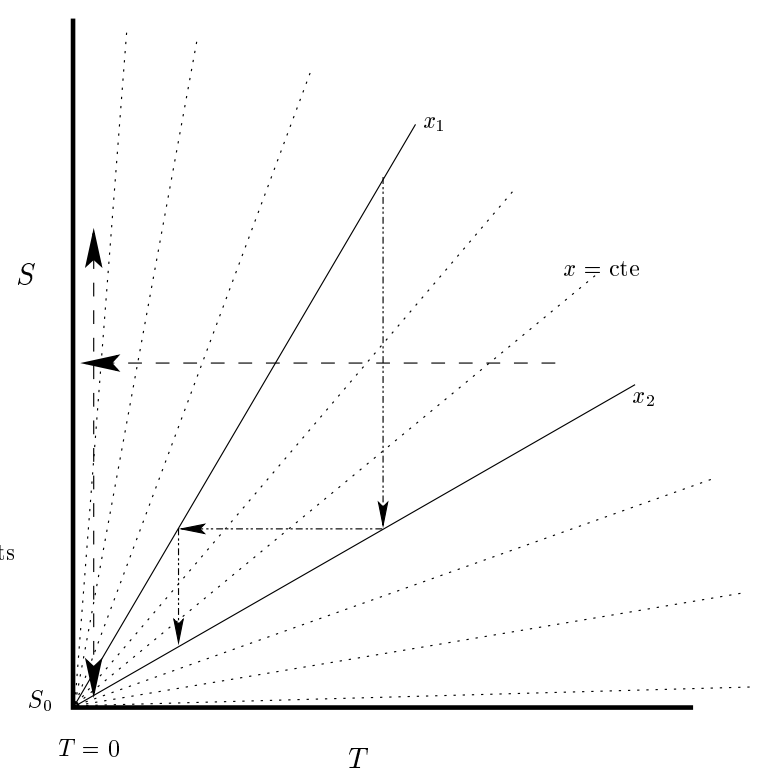

FIG. 1: Diagrama $T-S$ para el modelo (2). Se muestran líneas de iso- $x$. La inaccesibilidad del cero absoluto y (1) se satisfacen para valores dados de $x_{1}$ y $x_{2}$. Sin embargo, un proceso isentrópico - flecha horizontal- disminuye la temperatura del sistema en forma arbitraria. Cualquier alteración de entropía es también posible en las proximidades de $T=0$-flecha vertical- con tal que $x$ cambie de forma apropiada.

un único paso a través de $T x^{g}=$ cte. La "inaccesibilidad" de la isoterma cero sería una cuestión de limitaciones prácticas - cómo conseguir un $x$ infinito- en vez de una restricción expuesta por una ley de la naturaleza - estrictamente, el cero absoluto es accesible de forma asintótica.-

Finalmente, el modelo tampoco satisface la palabras de Nernst — véase la sección 1- No importa cuan cerca estemos del cero absoluto, cualquier alteración de la entropía es posible con tal que la variable mecánica aumente suficientemente.

El gas ideal se comporta de forma similar a este modelo. Una descripción clásica de las partículas lleva a una entropía que sin límite inferior y que no satisface el teorema de Nernst. Por el contrario, una descripción cuántica del problema lleva [10, 15, 18] a (2) donde $x$ es el volumen y $g=2 / 3$ para fermiones. Un análisis profundo del modelo muestra que la elección de una descripción cuántica o clásica está regida por la condición 10, 14]:

$$
\frac{V}{N}\left(\frac{m k T}{2 \pi \hbar^{2}}\right)^{3 / 2} \gg 1
$$

conocida como "límite clásico." Aquí $N$ es el número de partículas, $\hbar$ es la constante de Dirac, $m$ es la masa de las partículas y $k$ la constante de Boltzmann. Así, la competencia entre $T \rightarrow 0$ y $V \rightarrow \infty$ es, de nuevo, crucial. Probablemente estas contradicciones sólo reflejan el hecho de que las interacciones son 
necesarias en las cercanías del cero absoluto y modelos microscópicos ideales pueden no representar fielmente los datos experimentales sobre sistemas macroscópicos 14.

Hemos mostrado que un modelo que satisfaga (11) - la descripción clásica del teorema de Nernst - no conduce a la inaccesibilidad del cero absoluto. Aún peor no se ajusta a las palabras de Nernst. Nuevas hipótesis son necesarias para una descripción matemática precisa y completa de las leyes empíricas observadas a muy bajas temperaturas.

\section{EL TEOREMA DE NERNST COMO UN LÍMITE UNIFORME}

La descripción matemática del teorema de Nernst expuesta en la sección 1 1 mejora notablemente considerando la siguiente hipótesis I: el cambio isotermo de entropía tiende uniformemente a cero cuando la temperatura tiende a cero:

$$
\forall \epsilon>0 \quad \exists \delta(\epsilon)>0: T<\delta \Rightarrow\left|S\left(T, x_{1}\right)-S\left(T, x_{2}\right)\right|<\epsilon
$$

La clave de la "convergencia uniforme" es 26, 27] que el mismo $\delta(\epsilon)$ sirve para cualquier $x_{1}, x_{2}$ que pertenezcan a $\mathcal{D}$. Es inmediato que (3) satisface el enunciado puesto en la sección 11 Mostraremos que es la mejor forma de expresar matemáticamente la proposición de Nernst.

Nótese que, clásicamente, el teorema de Nernst restringe la dependencia funcional del cambio isotermo de entropía $\Delta S=S\left(T, x_{2}\right)-S\left(T, x_{1}\right)$ en $T$ de forma que converge a cero en el cero absoluto. La condición de "uniformidad" que aquí introducimos, significa esencialmente que ninguna valor de $x$ puede comprometer esta convergencia. Es decir, no es posible una divergencia accidental debida a un valor particular de $x$ en las cercanías del cero absoluto. En este sentido, el teorema de Nernst también restringe la dependencia funcional de $\Delta S(T, x)$ en $x$.

a. El papel de $x$ : Si la hipótesis se toma en consideración la variable mecánica no desempeña ningún papel en la descripción de problema. Esta es una consecuencia primaria de la convergencia uniforme puesto que dado $\epsilon$ entonces $\delta$ es sólo una propiedad del sistema objeto de estudio sin considerar los valores de $x$. El lector debe notar que éste es uno de los puntos claves de la formulación del teorema como ley natural que no dependa de la configuración de sistema objeto de estudio.

En la descripción clásica del teorema (1) $\delta$ es una función $\epsilon, x_{1}, x_{2}$ de forma que la variable mecánica sí desempeña un papel. Este papel normalmente no se considera en el problema pero es de gran importancia a la hora de considerar, por ejemplo, límites dobles.

b. Existencia de regiones inaccesibles en un diagrama $T-S$ : La ecuación (3) asegura que $S\left(T, x_{1}\right)-S\left(T, x_{2}\right)$ está acotada en las cercanías del cero absoluto de forma que tiene un supremo:

$$
\sigma(T)=\sup _{x \in \mathcal{D}}\left\{S\left(T, x_{1}\right)-S\left(T, x_{2}\right)\right\}
$$

La función $\sigma$ existe y es monótona creciente por lo menos en las cercanías de $T=0$. La función depende de las propiedades termofísicas del sistema objeto de estudio. Lo que sigue describe las propiedades más relevantes de esta función en estas cercanías.

Consideremos un sistema que satisface la hipótesis I cuyo estado de equilibrio esté definido por una temperatura y un valor del parámetro mecánico. La entropía del sistema vale $S(T, x)$. Auméntese la entropía del sistema de forma isoterma; la existencia de $\sigma$ asegura que la entropía final no puede exceder de $S(T, x)+\sigma$. El mismo argumento sirve para una disminución de entropía. Por lo tanto, $S(T, x)$ es una función de $x$ con cota superior en inferior para una temperatura dada, y existen las siguientes funciones:

$$
S_{\text {max }}(T)=\sup _{x \in \mathcal{D}}\{S(T, x)\} ; \quad S_{\text {min }}(T)=\inf _{x \in \mathcal{D}}\{S(T, x)\}
$$

Como la condición de estabilidad $(\partial S / \partial T)_{x}>0$ es válida en las cercanías de $T=0$-xcepto quizá en $T=0$ - las funciones anteriores son crecientes en $T$ de forma que estados del tipo $\left\{T, S>S_{\max }(T)\right\}$ y $\left\{T, S<S_{\min }(T)\right\}$ no pueden existir. Así, los estados de equilibrio no llenan el plano $T-S$ y dos fronteras aparecen si se cumple el teorema de Nernst como una condición uniforme.

Con más detalle podría decirse que uno de los grandes objetivos del tercer principio de la termodinámica es asegurar que la entropía tiene un único valor en la isoterma cero [9]. En la formulación clásica del teorema, se excluyen los puntos del tipo $\left\{T=0, S \neq S_{0}\right\} \underline{9}$, Figura 23.5] en un diagrama $T-S$ (estos puntos se representan por el símbolo $\times$ en la figura 2). Desde un punto de vista físico "cuando un punto es excluido debemos demandar lo mismo en una pequeña región alrededor del punto" [4] 28, pág. 236]. 30] Por el contrario si una cercanía de $\left\{T=0, S \neq S_{0}\right\}$ pudiera alcanzarse la exclusión de estos puntos - aislados - sería enteramente ficticia.

Así, el diagrama $T-S$ (véase la figura 2) consiste en una región I de valores permitidos de $\{T, S\}$, y la región II, prohibida. La existencia de esta región prohibida es una consecuencia de la hipótesis I. Las fronteras - que pueden o no ser accesibles - no coinciden con el eje $T=0$. En la figura 2 y en la discusión precedente hemos hecho uso de la hipótesis de Planck por claridad. El argumento también vale si la entropía $S_{0}$ tiende a $-\infty$ mientras que, simultáneamente, $\Delta S$ tiende a cero.

El siguiente punto es conocido, sin embargo la hipótesis I enriquece y clarifica su significado.

c. Procesos que terminan (enunciado de inaccesibilidad): Consideremos un proceso isentrópico $S=\Sigma_{0}$ que empieza a una temperatura tal que $S_{\text {min }}<\Sigma_{0}<S_{\text {max }}$. El proceso continua hasta una temperatura $T_{1}$ definida por $S_{\max }\left(T_{1}\right)=\Sigma_{0}$. Esta temperatura no es cero.

Aquí, podemos disminuir la entropía del sistema isotérmicamente hasta que la condición $\Sigma_{1}=\Sigma_{0}-$ 


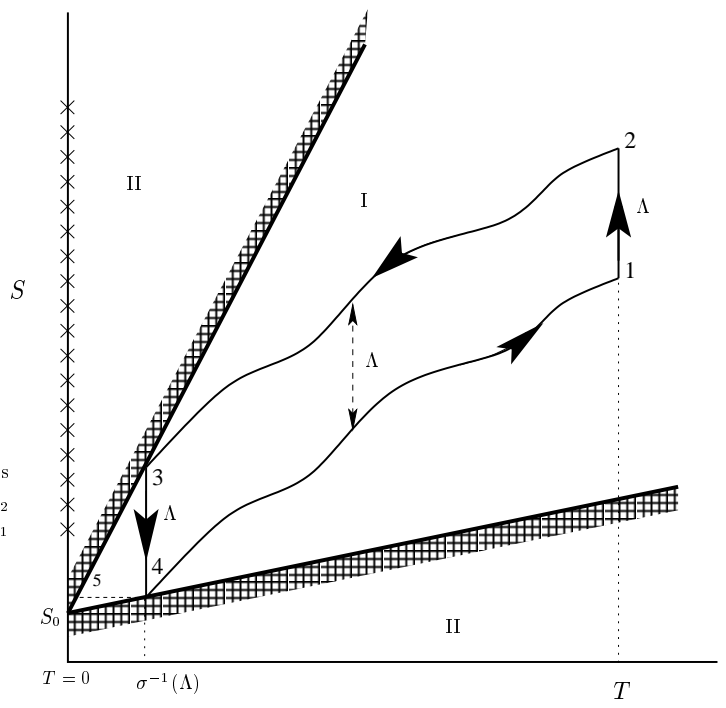

FIG. 2: El diagrama $T-S$ y el teorema de Nernst. El símbolo $\times$ representa los puntos excluido clásicamente por el teorema [9, Figura 23.5]. Un análisis más pausado del teorema revela que existe una región I cuyos puntos representan estados de equilibrio, y una región II que no lo hace. El ciclo 1-2-3-4-1 es una máquina constituida por dos isotermas 1-2 y 3-4 y dos procesos 2-3 y 4-1 que difieren en un transporte paralelo de entropía $S^{\prime}=S+\Lambda$. El área 1-2-3-4-1 es igual a $\Lambda\left[T-\sigma^{-1}(\Lambda)\right]$ como en una máquina de Carnot. La figura sirve incluso si $S_{0} \rightarrow-\infty$ mientras que $\Delta S \rightarrow 0$

$\sigma\left(T_{1}\right)=S_{\min }\left(T_{1}\right)$ se alcance. En este punto, un nuevo proceso isentrópico enfría el sistema hasta $T_{2}$ definida por $S_{\max }\left(T_{2}\right)=\Sigma_{1}$.

El proceso en escalera sin fin que lleva al cero absoluto ha quedado definido.

d. Anulación de los coeficientes de expansión térmica Los coeficientes de expansión térmica se relacionan con la derivada $(\partial S / \partial x)_{T}$ a través de relaciones de Maxwell [9]. De (3) se deriva la anulación de estas derivadas puesto que:

$\lim _{T \rightarrow 0}\left(\frac{\partial S}{\partial x}\right)_{T}=\lim _{T \rightarrow 0} \lim _{x^{\prime} \rightarrow x} \frac{S\left(T, x^{\prime}\right)-S(T, x)}{x^{\prime}-x} \quad \forall x \in \mathcal{D}$

Si el límite doble existe, puede calcularse en el orden que se desee. Tomando primero el límite en $T$ e invocando (3) se tiene, necesariamente que [9]:

$$
\lim _{T \rightarrow 0}\left(\frac{\partial S}{\partial x}\right)_{T}=0 \quad \forall x \in \mathcal{D}
$$

Debe destacarse que las propiedades c y d son hechos físicos ampliamente confirmados por la experiencia [6, 9], al contrario que las proposiciones a y b que son de carácter matemático. Estos hechos físicos son los que dan soporte a la hipótesis. Sin embargo, la más importante de las consecuencias de esta hipótesis tiene que ver con el problema de la conversión del calor en trabajo y será explicada con detalle en la siguiente sección.

\section{EL TEOREMA DE NERNST Y LA PRODUCCIÓN DE TRABAJO}

En la sección precedente hemos mostrado que el teorema de Nernst fuerza la existencia de regiones prohibidas en el plano $T-S$. Ahora derivaremos consecuencias teniendo en cuenta que la condición de uniformidad introducida en la sección anterior hace que $x$ no desempeñe papel en el problema.

Consideramos la siguiente cuestión: queremos construir un motor que produzca un trabajo mecánico $W$ usando un fluido de trabajo dado y que extraiga una cantidad de calor dada de un foco térmico de temperatura también dada; ¿cuál es la mínima cantidad de calor que ha de depositarse en el foco frío? 31.

La lectura clásica del enunciado de Kelvin-Planck sólo precisa que el calor cedido al foco frío - en adelante "compensación" - debe ser no nulo $Q^{\prime} \neq 0$. Parece que en lo que se refiere a este enunciado un valor de $Q^{\prime}$ despreciable es válido. Así, $Q_{\min }^{\prime}=0^{+}$-i.e. arbitrariamente próximo a cero pero mayor que cero.Esta respuesta es independiente de $Q, T$ y del fluido de trabajo y proviene del hecho de que se tiene la impresión de que un ciclo de Carnot puede situarse libremente dentro de un diagrama $T-S$ puesto que no hay más restricción más que $Q^{\prime} \neq 0$.

Una máquina que tuviera $Q_{m i n}^{\prime}=0^{+}$daría un rendimiento $\eta=W / Q$ tan próximo a la unidad como se quiera. Nunca se ha construido una máquina tan eficiente, ahora mostraremos que esto se debe a limitaciones fundamentales de la materia, con independencia de las limitaciones de índole práctico que pudieran surgir.

Como regla general, $\sigma$ (4) es no nula para temperaturas no nulas y de (3) y (41) se obtiene:

$$
\forall \epsilon>0 \quad \exists \delta(\epsilon)>0: \quad T<\delta \Longrightarrow \sigma(T)<\epsilon
$$

Es decir, $\lim _{T \rightarrow 0^{+}} \sigma(T)=0$.

En (7) no hay ninguna necesidad de colocar los símbolos de valores absolutos puesto que $T$ y $\sigma$ son cantidades positivas. De (7) y del argumento precedente se deduce inmediatamente la existencia de la función inversa $\sigma^{-1}(\Lambda)$. De hecho, la función inversa no es más que una representación adecuada del parámetro $\delta(\epsilon)$. La función inversa señala la temperatura a la que la anchura en entropía de los estados accesibles es, justamente, $\Lambda$. Esta temperatura depende de las propiedades termofísicas del sistema objeto de estudio.

Consideremos entonces la pregunta señalada al principio de esta sección pero consideremos ahora se cumplen el enunciado de Kelvin-Planck y el teorema de Nernst tal y como se expuso en la sección 11 Por tanto, las restricciones expuestas en la sección [3] y mostradas en la figura 2 son válidas. El fluido de trabajo realiza un ciclo en el que extrae una cantidad de entropía $\Lambda=Q / T$ de la fuente caliente. Para ello es necesario que $\Lambda<\sigma(T)$.

Esta entropía debe devolverse en el foco frío que recibiría una cantidad de calor $Q^{\prime}$. Para alcanzar el máximo rendimiento, la temperatura de este foco debe 


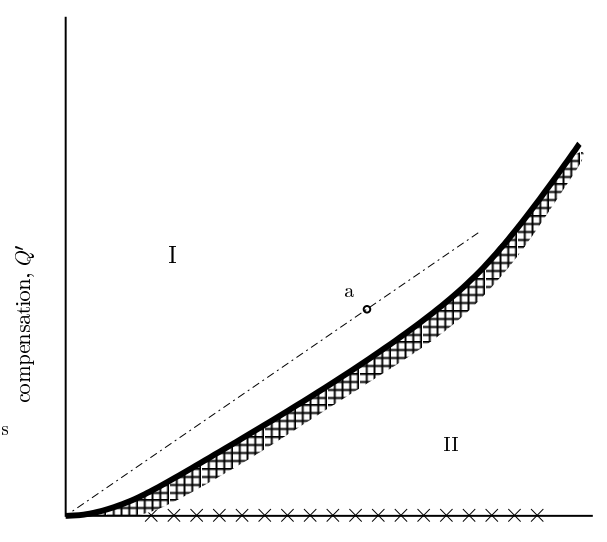

exchange of entropy, $\Lambda=\frac{Q}{T}$

FIG. 3: Diagrama $\Lambda-Q^{\prime}$ para una sustancia de trabajo. Un punto de la región I, pro ejemplo $a$, representa un conjunto de máquinas que depositan todas ellas la misma cantidad de calor $Q^{\prime}$ en el foco frío, e intercambian la misma cantidad de entropía entre el foco caliente y el frío. La línea gruesa - que depende del fluido de trabajo - representa (8) y tiende a $\{0,0\}$ con pendiente cero. Para un fluido de trabajo, es imposible construir una máquina que se sitúe en la región II. El símbolo $\times$ representa la restricción expuesta por el enunciado de Kelvin-Planck en su lectura clásica.

ser la menor de las posibles capaces de intercambiar esta cantidad de entropía con este fluido de trabajo. Siguiendo los argumentos expuestos en los párrafos anteriores se deduce que esta temperatura mínima viene dada por $\sigma^{-1}(\Lambda)$ que es una propiedad del fluido objeto de estudio. Por tanto,

$$
\begin{array}{r}
\forall Q \neq 0, T \neq 0: \frac{Q}{T}=\Lambda<\sigma(T) \\
\Longrightarrow \exists \sigma^{-1}(\Lambda): Q^{\prime} \geq \Lambda \times \sigma^{-1}(\Lambda)=Q_{\text {min }}^{\prime}
\end{array}
$$

Esta máquina se representa en la figura 2 por el ciclo $1-2-3-4-1$ constituido por dos isotermas y dos procesos en los que se produce un transporte paralelo de entropía; los intercambios de energía y entropía en $2-3$ se cancelan con los de $4-1$ de forma que las fuentes involucradas en estos procesos no desempeñan ningún papel en el problema. 32 El trabajo producido es igual a $W_{\max }=\Lambda \times\left[T-\sigma^{-1}(\Lambda)\right]$.

El valor de $Q_{\min }^{\prime}$ es una función de los parámetros del problema: $Q, T$ y el fluido de trabajo que entra a través de $\sigma^{-1}$. Además la compensación mínima es sólo función del intercambio de entropía $\Lambda$.

Aunque el valor de $Q_{\text {min }}^{\prime}$ depende, para cada situación, de las propiedades del fluido de trabajo, es un hecho muy destacable que, como regla general, $Q_{m i n}^{\prime}$ no puede ser una cantidad arbitrariamente próxima a cero para un $\Lambda$ dado puesto que, según el teorema de Nernst, $\sigma^{-1}$ tampoco lo es (véase la figura 21).

El carácter universal de (8) permite dibujar un diagrama $\Lambda-Q^{\prime}$ (véase la figura [3). Obsérvese que en el contexto de la lectura clásica del enunciado de
Kelvin-Planck este diagrama no tendría más restricción que la exclusión de los puntos $\left\{\Lambda \neq 0, Q^{\prime}=0\right\}$, que son destacados en la figura por el símbolo $\times$. Pero si ahora tenemos en cuenta el teorema de Nernst es evidente que puntos del tipo $\left\{\Lambda, Q^{\prime}<Q_{m i n}^{\prime}(\Lambda)\right\}$ tampoco son posibles. Estos puntos definen una región cuya frontera viene dada por (8); la analogía entre las regiones I y II y la frontera dibujadas en la figura 2 con aquellas de la figura 3 es inmediata. Del teorema de Nernst se deduce fácilmente que $Q_{m i n}^{\prime}$ tiende a cero con pendiente cero cuando $\Lambda$ tiende a cero. Resumiendo el significado de la figura 3 debe destacarse que el teorema de Nernst excluye una región alrededor de los puntos realmente excluidos por la lectura clásica del enunciado de Kelvin-Planck. Esto está de acuerdo con las palabras de Carathéodory expuestas en la sección 3

El límite $\Lambda \rightarrow 0^{+}$es la única forma de conseguir $Q_{m i n}^{\prime} \rightarrow 0^{+}$. En este caso, y tomando $T$ como una constante acotada, es claro que $Q$ también tiende a cero y, como consecuencia, también el trabajo. Por tanto:

$$
Q^{\prime} \rightarrow 0^{+} \Longrightarrow W \rightarrow 0^{+}
$$

Esta proposición contiene la esencia del teorema de Nernst. Su significado más dramático se observa mejor si se nota que $Q^{\prime} \rightarrow 0^{+}$y $\eta \rightarrow 1^{-}$son equivalentes. Señala por tanto que conforme se consigue la máquina más eficiente, la producción de trabajo va disminuyendo hasta cero.

Debe destacarse una vez más que en la discusión precedente $x$ no desempeña ningún papel y en este sentido las restricciones de la figura 3 y (9) son universales. Este hecho proviene de la uniformidad. Si, al contrario, el teorema de Nernst se lee como un simple límite - sin el requerimiento de uniformidad - entonces (9) y la figura 3 son sólo válidas para transiciones entre dos valores dados de $x$ - véase [9, Figura 23.9] 23].- - Por lo tanto, (11) no conduce a ninguna restricción real ya que la frontera de la figura 3 puede situarse tan próxima a la restricción expuesta por la lectura clásica del enunciado de Kelvin-Planck con tal de que se consideren valores apropiados de $x_{1}$ y $x_{2}$. Así, la mejora del rendimiento de cualquier máquina sería una cuestión de limitaciones prácticas si (10) fuera valida. 33.

\section{EL TEOREMA DE NERNST Y EL ENUNCIADO DEL SEGUNDO PRINCIPIO}

La sección 4 muestra claramente que el teorema de Nernst restringe la conversión del calor en trabajo en una forma que es independiente de la configuración mecánica del sistema. Es deseable un enlace entre el enunciado del segundo principio y el teorema.

Uno de los resultados más importantes de la sección 4 es el importante papel que desempeña $Q^{\prime}$, la compensación, en el problema de la conversión del calor en trabajo. Su importancia proviene del hecho de que su valor mínimo viene dado por una expresión universal (8). 


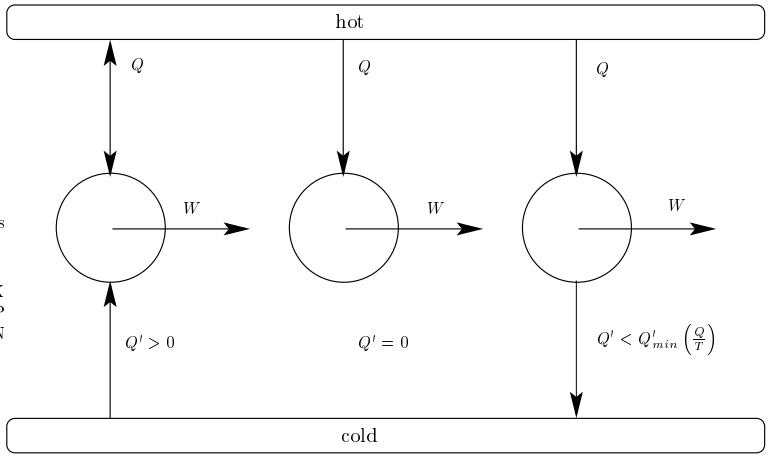

FIG. 4: La secuencia de enunciados del segundo principio. El lector debe reconocer las restricciones sobre la compensación que provienen de la violación de los diferentes enunciados. De izquierda a derecha, una violación del enunciado de Kelvin, una violación de la lectura clásica del enunciado de KelvinPlanck, y una violación de una lectura más razonada de este enunciado y que incluye el teorema de Nernst. En este último caso $Q_{m i n}^{\prime}$ viene dado por (8).

Desde un punto de vista estrictamente histórico el papel del foco frío has sido la clave de los enunciados del segundo principio. Así, el primer enunciado - debido a Kelvin 2],- expresa que es imposible construir una máquina que, a la vez, produzca trabajo y enfríe la más fría de las fuentes disponibles, sin importar qué ocurra con otras fuentes - más calientes - (véase la figura 44).

Planck simplificó el enunciado al notar que es imposible construir una máquina que produzca trabajo enfriando sólo una fuente[1]. En este sentido, una fuente más fría debe calentarse en una cierta cantidad - compensación(véase la figura 4). Sin embargo, como no incluyó ninguna condición sobre el "tamaño" de la compensación, se espera que pueda ser tan pequeña como sea posible: esta es la lectura "clásica" del enunciado de KelvinPlanck que se ha mantenido desde su formulación por Planck.

Pero además, si el teorema de Nernst entra en consideración a través de la hipótesis I, se obtiene la última restricción del problema: una compensación mínima queda determinada por las propiedades de la sustancia de trabajo y el intercambio de entropía (véase (8) y la figura 4): si se quiere transformar una cantidad finita de calor en trabajo hay que pagar, efectivamente, un impuesto —una compensación-es decir el impuesto no puede hacerse indefinidamente pequeño por voluntad del experimentador. 34 El texto con énfasis es un enunciado informal de (9).

El lector debe notar que, de hecho, (9) es algo más que el simple enunciado del teorema de Nernst puesto que incide sobre el problema del enunciado de Kelvin-Planck. Es el dintel que corona el leitmotiv de los principios de la termodinámica al señalar la última restricción sobre la compensación. Si esta relación se describiera en forma negativa nos encontraríamos con algo muy parecido a un enunciado del segundo principio: prohibe la producción de un trabajo finito sin una compensación finita.

\section{DEL ENUNCIADO DE KELVIN-PLANCK AL TEOREMA DE NERNST}

Las secciones anteriores han analizado el teorema de Nernst a través de la hipótesis I poniendo de manifiesto su relación con el problema de la conversión del calor en trabajo. Ahora deseamos realizar el viaje contrario: comenzando por el enunciado de Kelvin-Planck, ¿bajo qué circunstancias se obtiene la hipótesis I?

En nuestra opinión puede decirse que la lectura clásica del enunciado de Kelvin-Planck es "cruda" en el sentido de que la causa - el calor absorbido por de la fuente caliente - y el efecto inevitable - la compensación mínima - se han considerado desacopladas desde los comienzos de la termodinámica. Una lectura más razonada del enunciado del segundo principio debió haber concluido que debe existir un cierto acoplamiento entre $W_{\max }$ o $Q_{\min }$ y $Q$ puesto que sólo una cantidad inifinitesimalmente pequeña de $Q$ puede dar lugar a una compensación infinitesimalmente pequeña. Ahora señalaremos que esta hipótesis - hipótesis II - es suficiente para el teorema de Nernst:

\section{la compensación de una máquina de Carnot tiende a cero sólo si el calor absorbido del foco caliente tiende a cero}

La importancia de la hipótesis vendrá dada por las conclusiones que se deriven de ella pero, antes de nada el lector no debe tomarla como una hipótesis adicional al enunciado de Kelvin-Planck puesto que está incluida, implícitamente, en las palabras del enunciado. La clave de la cuestión es la palabra "efectos" que aparece en el enunciado. Se puede conseguir explícitamente la hipótesis II si se sustituye esta palabra por "efectos finitos" de forma que todo calor absorbido "finito" conduzca, necesariamente, a una compensación "finita". Sin embargo ha de entenderse que todo "efecto" es, por definición, "finito" y por tanto está modificación es un pleonasmo incompatible con la descripción en palabras de una ley de la naturaleza.

El hecho de que la hipótesis II conduzca el teorema de Nernst es, sorprendentemente, elemental. Téngase en cuenta que la compensación de una máquina equivale a $Q^{\prime}=T^{\prime} \times \Lambda$ donde $T^{\prime}$ es la temperatura del foco frío y $\Lambda$ la entropía intercambiada. Esta expresión puede hacerse cero (1) si $T^{\prime}$ tiende a cero, con independencia de lo que haga $\Lambda$, o (2) si $\Lambda$ tiende a cero con independencia de lo que haga $T^{\prime}$. La hipótesis excluye la opción (1), es decir excluye cualquier cambio de entropía en las cercanías del cero absoluto. Por tanto, el teorema de Nernst, tal y como se enunció en la sección 1y se analizó en la sección 3 queda demostrado.

Se concluye entonces que las hipótesis I y II son proposiciones equivalentes de forma que el teorema de Nernst proviene, en última instancia, de una lectura 
razonada del enunciado de Kelvin-Planck a través de la hipótesis II. 35] Esta proposición es válida, al menos en tanto que nos refiramos a sistemas capaces de convertir calor en trabajo.

\section{DISCUSIÓN Y CONCLUSIÓN}

En 1909 Carathéodory [4], siguiendo una sugerencia de Born, consiguió traducir los enunciados clásicos del segundo principio - que hablan del problema de la conversión del calor en trabajo- en un enunciado que habla de las propiedades de un sistema aislado. Este trabajo presenta el camino contrario para el teorema de Nernst. Se ha supuesto que el teorema expresa propiedades de los sistemas en las cercanías de $T \rightarrow 0$; el estudio que aquí presentamos (véase la sección 4 especialmente (8) y (9) ) relaciona el teorema con el problema de la producción de trabajo. Estaría expresando una propiedad universal que debe satisfacer toda motor térmico.

El lector puede preguntarse qué hipótesis hacen al teorema de Nernst independiente del enunciado de Kelvin-Planck y cuáles no. El objetivo del segundo principio es restringir la producción continua de trabajo señalando una asimetría fundamental: el trabajo puede disiparse en forma de calor pero lo contrario no. Este objetivo se manifiesta en un enunciado que expresa, en palabras, una restricción. Lo que hemos mostrado en este trabajo es que el grado de restricción importa y tiene influencia en las propiedades de los sistemas. La lectura clásica del enunciado de Kelvin-Planck asume sólo que la compensación es non nula. Con esta lectura, las propiedades de los sistemas en las cercanías de $T=$ 0 tiene que venir expresadas por una ley adicional e independiente. Sin embargo, una lectura más razonada, a través de la hipótesis II presentada en la sección 6 conduce a alguna de estas propiedades: la inaccesibilidad del cero absoluto y la anulación de los coeficientes de expansión térmicos. Sin embargo, señalamos de nuevo que la formulación es insensible a la cuestión de si los calores específicos se anulan o no en el cero absoluto.

La nueva lectura del enunciado evita el embarazoso hecho de que $W$ debe diferir de $Q$ - la cuestión es ¿en qué cantidad deben diferir? - señalando que deben hacerlo en una cantidad mensurable que depende de la sustancia de trabajo la cual también desempeña un papel en el problema. Las palabras de Carathéodory citadas en la sección [3] vuelven a dar en el clavo: si la condición $W=Q$ ha de excluirse, $W=Q^{-}$también debió haberse excluido. 36.

Una excepción a las hipótesis aquí presentadas resultaría en un fallo de las consecuencias b y c expuestas en la sección la sección 3 es decir: (i) una experiencia que permitiera aumentar $1 / T$ indefinidamente, (ii) una experiencia que permitiera disminuir la entropía de forma indefinida, o (iii) una sustancia cuyos coeficientes de expansión térmica no se anulasen en el cero absoluto. 37]

Esta fuera del ámbito de este trabajo describir las relevancia microscópica de nuestras hipótesis, es decir determinar qué tipo de hamiltonianos - interaccionesconducen a una entropía que se desvanece uniformemente en $T=0$ así como las propiedades de simetrías de estos hamiltonianos. Modelos reconocidos - especialmente gases ideales - no satisfacen estas hipótesis. Sin embargo, el lector no debe concluir que esto sea una "excepción" a las hipótesis puesto que éstas sólo se fundamentan en datos experimentales macroscópicos y no en el análisis de modelos.

La relación entre modelos no interaccionantes y el teorema de Nernst ha sido sugerida recientemente 14, 17. y parece inevitable la presencia de interacciones en las cercanías del cero absoluto. Esta sugerencia proviene del análisis del modelos de espines independientes que no satisface el teorema de Nernst puesto que su estado fundamental es degenerado. Sin embargo, este tipo de sistemas no se presenta en la naturaleza puesto que los sólidos reales exhiben ordenación y correlación de espines a temperaturas suficientemente bajas. La ordenación resultante - usualmente una nueva fase ferromagnética o antiferromagnética - sí satisface el teorema.

Un análisis similar vale para sistemas de partículas. El lector debe notar que el gas ideal clásico permite imaginar procesos del tipo (i) y (ii), además no satisface (iii) en contradicción con el teorema de Nernst. Por su parte, el gas ideal cuántico 10] dan coeficientes de expansión térmica nulos en el cero absoluto, y excluyen experiencias del tipo (ii) puesto que la entropía está acotada. Sin embargo aún permiten experiencias del tipo (i) que no ocurren en la naturaleza y que violan en significado del teorema de Nernst. Por supuesto en sistemas reales la "ordenación" está siempre presente y la formación de fases condensadas parece inevitable.

Es muy posible por tanto que modelos no interaccionantes - sean cinéticos, magnéticos o de cualquier otra índole - no describen de forma precisa las propiedades de los sistemas reales a temperaturas suficientemente bajas puesto que las interacciones no pueden ser despreciadas en este caso.

\section{Agradecimientos}

Los autores desean mostrar su gratitud para con D. José Antonio Pérez Gómez por las largas discusiones mantenidas y, especialmente, por iluminarlas con el concepto de convergencia uniforme. También agradecen a Dña. Pilar Núñez su amable búsqueda de registros bibliográficos antiguos. Este trabajo has sido financiado por el Ministerio de Ciencia y Tecnología de España bajo el proyecto BFM2002-02237. 
[1] M. Planck, Treatise on Thermodynamics (Longmans, 1927).

[2] W. Thomson, Trans. Roy. Soc. Edinb. 20, 261 (1853).

[3] R. Clausius, Ann. Phys. Lpz. xciii, 481 (1854).

[4] C. Carathéodory, Mathematischen Annalen 67, 355 (1909).

[5] W. Nernst, Nach. kgl. Ges. Wiss. Göttingen 1 (1906).

[6] W. Nernst, The New Heat Theorem: Its Foundations in Theory and Experimental (Dover, 1924).

[7] A. Einstein, in La structure de la matière (GauthiersVillars, 1921), Rapports et discussion du Conseil de Solvay (1913), pp. 294-295.

[8] P. Epstein, A Textbook of Thermodynamics (John Wiley and Sons, 1937).

[9] J. Kestin, A course in Thermodynamics, vol. II (Blaisdell Pub. Co., 1968).

[10] L. Landau and E. Lifshitz, Statistical Physics (Pergamon Press, 1968).

[11] P. Landsberg, Thermodynamics and Statistical Mechanics (Oxford Univ. Press, 1978), ISBN 0-19-851142-6.

[12] R. Baierlein, Thermal Physics (Cambridge University Press, 1999), ISBN 0-521-65838-1.

[13] M. Zemansky, Heat and Thermodynamics (McGraw-Hill, 1968).

[14] R. Balian, From microphysics to macrophysics (Springer Verlag, Berlin Heidelberg, 1991), ISBN 0-387-53266-8.

[15] K. Huang, Statistical Mechanics (John Willey and Sons, 1987), ISBN 0-471-85913-3.

[16] S. Mafé and J. de la Rubia, American Journal of Physics 66, 277 (1998).

[17] C. Rose-Innes, American Journal of Physics 67, 27 (1999).

[18] J. Wu and A. Widom, Physical Review E 57, 5178 (1998).

[19] G. Falk, Physical Review 115, 249 (1959).

[20] Z. Yan and J. Chen, Journal of Physics A: Math. Gen. 21, 707 (1988).

[21] P. Landsberg, Journal of Physics A: Math. Gen. 22, 139 (1989).

[22] I. Oppenheim, Journal of Physics A: Math. Gen. 22, 143 (1989).

[23] R. Liboff, Physics Essays 7, 95 (1994).

[24] P. Landsberg, American Journal of Physics 65, 269 (1997).

[25] F. Belgiorno, Journal of Physics A: Math. Gen. (2003), physics/0210037.

[26] D. Jones, Funciones Generalizadas (Urmo, Bilbao, 1972).

[27] D. Jones, The theory of generalised functions (Cambridge University Press, 1982), ISBN 0521237238.

[28] J. Kestin, ed., The Second Law of Thermodynam- ics, vol. 5 of Benchmark Papers on Energy (Dowden, Hutchinson \& Ross, Inc., 1976).

[29] El propio Nernst describió (1) a través del enunciado expuesto en la sección 1 [6, pág. 85]

[30] Aquí, Carathédory está hablando sobre la inaccesibilidad adiabática y prepara su conocido Axioma II. Debe destacarse que el axioma dice, literalmente, que"(...) existen estados a cuyas cercanías no puede accederse arbitrariamente por un proceso adiabático" en vez del concepto "estados que son inaccesibles por un proceso adiabático." El concepto "arbitrariamente próximo" desempeñan un papel importante en la discusión posterior.

[31] La cuestión analiza el comportamiento de $W$ o $Q^{\prime}$ - puesto que el foco caliente y el calor absorbido están dados. Es también normal preguntarse por el comportamiento de $W$ cuando el foco frío y caliente están dados. Este es un problema relacionado con el concepto de irreversibilidad[10] y esta fuera del objeto de esta discusión.

[32] Sería posible disminuir $Q^{\prime}$ si se considera el ciclo $1-2-$ $3-5-4-1$ - véase la figura 2] porque la entropía sería intercambiada con focos de menor temperaturas; sin embargo la condición de dos focos se rompe. Incluso en este caso, la compensación se expresa por $\sigma^{\prime \prime} \Lambda$ donde $\sigma^{\prime \prime}$ es una temperatura desconocida perteneciente al intervalo entre $T_{5}$ y $T_{4}=\sigma^{-1}(Q / T)$. La discusión que sigue es válida, igualmente, para esta compensación

[33] Si la sustancia de trabajo se comporta como (2), la máquina conseguiría mejores eficiencias si se alcanzan valores mayores de $x$.

[34] En la naturaleza no existen "paraísos fiscales".

[35] Así, el segundo principio garantiza que la entropía tiende a un único valor - que no depende de $x$ - cuando la temperatura tiende a cero. El valor de la entropía en el cero absoluto, o específicamente si es finito o infinito - formulación de Planck - es ajeno al análisis realizado en este artículo puesto que el segundo principio sólo es sensible a variaciones de entropía y el problema de su valor absoluto queda indeterminado.

[36] Presentamos una analogía entre las palabras de Carathéodory y los resultados de este trabajo. No es intención de los autores señalar que lo uno derive de lo otro o al revés. Es una coincidencia que ambos problemas traten sobre la misma ley natural.

[37] El lector debe observar que la inaccesibilidad del cero absoluto no garantiza el teorema de Nernst. El modelo $S(T, x)=\chi \log T \times(x+a) /(x+b)$ con $\chi, a \neq b>$ $0, x \in \mathbb{R}^{+}$muestra un ejemplo matemático de sistema que excluye experimentos del tipo (i) y (ii) pero no satisface el teorema de Nernst. 